\title{
Salivary SCD14 as a potential biomarker of dental caries activity in adults
}

\author{
Ljerka Prester $^{1}$, Nives Protrka ${ }^{2}$, Jelena Macan ${ }^{1}$, and Marina Katunarić ${ }^{3}$ \\ Institute for Medical Research and Occupational Health ${ }^{1}$, Private dental practice ${ }^{2}$, Zagreb University School of Dental \\ Medicine ${ }^{3}$, Zagreb, Croatia
}

[Received in April 2017; Similarity Check in April 2017; Accepted in November 2017]

\begin{abstract}
CD14 is a co-receptor involved in the recognition of Gram-negative and Gram-positive bacteria, the latter known to cause dental caries. The aim of this study was to determine whether soluble CD14 (SCD14) in saliva was associated with caries activity and the collection method from the saliva. The study included 55 participants aged 20 to 40 years, 30 with dental caries and 25 caries-free controls. We collected 110 saliva samples in total, 55 of resting saliva and 55 of mechanically stimulated saliva. Median levels of sCD14, measured with a matrix-matched enzyme-linked immunosorbent assay (ELISA), were higher in the caries-active than in the caries-free group in either resting $\left(203.3 v s .167 .9 \mathrm{ng} \mathrm{mL}^{-1} ; \mathrm{P}<0.01\right)$ or stimulated saliva (201 vs. $\left.105.7 \mathrm{ng} \mathrm{mL}^{-1} ; \mathrm{P}<0.01\right)$. The resting salivary flow rate was lower in the caries-active than caries-free group $\left(0.61 \pm 0.42\right.$ vs. $\left.0.98 \pm 0.52 \mathrm{~mL} \mathrm{~min}^{-1} ; \mathrm{P}<0.01\right)$. Hyposalivation was observed only in the caries-active group (10 and $13 \%$ in stimulated and resting saliva, respectively). Higher salivary sCD14 levels and secretion rates were clearly associated with dental caries and resting saliva. Future studies should focus on the clinical utility of salivary sCD14 as a potential biomarker and predictor of future caries events.
\end{abstract}

KEY WORDS: ELISA; hyposalivation; resting saliva; salivary flow rate; stimulated saliva

Dental caries is the localised destruction of susceptible dental hard tissue caused by complex interactions between cariogenic bacteria, fermentable carbohydrates, and host factors $(1,2)$. Common virulence factors among the Gramnegative bacteria are endotoxins (whose biologically active components are lipopolysaccharides, LPS) and among the Gram-positive bacteria it is the lipoteichoic acid $(3,4)$. Both LPS and lipoteichoic acid bind to the CD14 co-receptor, which is a $55-\mathrm{kDa}$ glycoprotein (5). One of the CD14 functions is to neutralise LPS and other microbial constituents (peptidoglycans, lipoteichoic acids) and transfer LPS to the transmembrane toll-like receptors (TLRs) $(6,7)$. Depending on the localisation, the CD14 receptor exists in two forms. The membrane bound CD14 (mCD14) is expressed on the surface of macrophage-like cells (monocyte, macrophage), activated neutrophils, and numerous non-myeloid cells including gingival fibroblasts $(5,6,8)$. The soluble form (sCD14), spontaneously released by these cells, circulates in the serum in high amounts $\left(2-4 \mu \mathrm{g} \mathrm{mL}^{-1}\right)$ and interacts with the LPS-binding protein (LBP) (9). The LPS/LBP/CD14 ternary complex interacts with TLRs, which leads to cell activation (10). Gingival epithelial cells, which are the first to encounter periodontal pathogens, express mostly TLRs. The bacterial activation of TLR-2 and TLR-4 in oral tissue may trigger multiple signalling pathways and the synthesis of inflammatory

Correspondence to: Ljerka Prester, Institute for Medical Research and Occupational Health, Ksaverska cesta 2, HR-10001 Zagreb, Croatia, E-mail:prester@imi.hr cytokines and chemokines that promote destruction of the periodontal tissue $(11,12)$. This highlights the importance of monitoring these immunocompounds in dental caries development $(13,14)$.

The prevalence of dental caries in European adults has been on a steady rise, urging for better dental caries prevention strategies (12). Saliva is essential for caries prevention, as it clears the bacterial substrate from dental plaque $(15,16)$, and if salivation is low due to a variety of reasons, caries risk increases (17). Saliva production can be reduced by medical treatment (xerogenic drugs), some autoimmune diseases (Sjögren's syndrome, systemic lupus erythematosus), dehydration, or head and neck irradiation $(18,19)$. Other factors which influence salivary flow rate include age, sex, circadian rhythm, gum chewing, and saliva collection methods $(16,19)$.

However, not only salivary flow or volume can predict the risk of caries, but also its immunity markers. The problem is, however, that the methods of saliva collection are not standardised (20-22), which may affect findings and interpretation. Recently, $\mathrm{sCD} 14$ was proposed as a salivary marker of inflammation in early childhood caries (23). To the best of our knowledge, there are no validated and commercially available enzyme-linked immunosorbent assays (ELISA) to quantify sCD14 in human saliva. Furthermore, salivary sCD14 in adults with dental caries has poorly been investigated.

The aim of our study was therefore to fill these gaps by 1) adopting and validating an ELISA to quantify sCD14 
concentrations in saliva, 2) comparing salivary sCD14 concentrations under the resting (unstimulated) and stimulated conditions, and 3 ) determining salivary flow rates and $\mathrm{SCD} 14$ secretion rates in dental caries-active and caries-free participants.

\section{PARTICIPANTS AND METHODS}

\section{Participants}

The study was conducted in Zagreb, Croatia in 2014 and included 30 dental caries-active and 25 caries-free controls. All had signed an informed consent prior to enrolment and the study was approved by the ethics committee of the Zagreb University School of Dental Medicine. The exclusion criteria were deep periodontal pockets, acute or chronic inflammation/infection (oral or systemic), malignancy, diabetes mellitus, pregnancy, or antibiotic therapy. Table 1 shows the demographic, lifestyle, and medical information of the enrolled participants.

\section{Sample size estimation}

The sample size was calculated based on the sCD14 concentration as the main outcome measure. All of the calculations were based on the two-tailed Mann-Whitney $U$ test, assuming the significance level of 0.05 and statistical power of 0.8 . Based on literature data for resting salivary sCD14 concentrations of healthy subjects (mean $=6.57 \mathrm{ng} \mathrm{mL}^{-1}$, $\mathrm{SD}=3.70)(10)$, the sample size sufficient to detect a meaningful sCD14 increase of at least $50 \%$ in the cariesactive group was calculated to be 22 per group. This sample size was also sufficient for stimulated salivary SCD14 (based on the estimates in the caries-free group, since there was no other literature available). Our sample size (30 in the caries-active and 25 in the caries-free group) was therefore sufficient to test the hypothesis that sCD14 concentrations would vary between these groups. All of the power calculations were performed with the G*Power Program, version 3.1.9.2 (University of Düsseldorf, Düsseldorf, Germany) (24).

\section{Dental examination}

All participants were examined by an experienced dentist for cavities (as the defining distinction between the groups) and clinical symptoms associated with caries: gingival bleeding, dryness of mouth, and the burning mouth syndrome. The DMFT index was expressed as the sum of the number of decayed (D), missing (M), and filled (F) teeth according to the criteria defined by the World Health Organization (25). To test the reproducibility and agreement between the scores, ten participants were examined for tooth decay on two separate occasions. The intra-examiner reliability had a kappa of 0.857 , which indicates a very high level of agreement.

\section{Saliva collection}

We collected 55 resting and 55 stimulated saliva samples between 8-11 am and 2-4 pm. Two hours before collection, the participants were asked to refrain from eating, drinking, smoking, and brushing teeth to obtain a relatively constant baseline. The resting saliva was collected before the stimulated one using the passive drool method as described earlier (21). The salivary flow rate $\left(\mathrm{mL} \mathrm{min}^{-1}\right)$ was calculated from the saliva volume collected over that one minute and divided in three categories: very low $\left(<0.1 \mathrm{~mL} \mathrm{~min}^{-1}\right.$, as a diagnostic criterion for hyposalivation), low (0.1$\left.0.2 \mathrm{~mL} \mathrm{~min}^{-1}\right)$, and normal $\left(>0.2 \mathrm{~mL} \mathrm{~min}^{-1}\right)$ (19).

To stimulate salivation, the participants were asked to chew $1.5 \mathrm{~g}$ of pure paraffin wax (Parafilm ${ }^{\circledR}$, American National Can, Greenwich, CT, USA) for five minutes without swallowing. The volume of stimulated saliva was then measured as described for the unstimulated saliva above and the flow rate calculated. The obtained flow rates were divided in three categories: very low $\left(<0.7 \mathrm{~mL} \mathrm{~min}^{-1}\right.$, as diagnostic criterion for hyposalivation), low (0.7$\left.1.0 \mathrm{~mL} \mathrm{~min}^{-1}\right)$, and normal $\left(>1.0 \mathrm{~mL} \mathrm{~min}^{-1}\right)(26,27)$.

Salivary sCD14 secretion rates $\left(\mathrm{ng} \mathrm{min}^{-1}\right)$ were calculated from the saliva volume $(\mathrm{mL})$ in one minute and the corresponding $\mathrm{SCD} 14$ concentration $\left(\mathrm{ng} \mathrm{mL}^{-1}\right)$.

All saliva samples were collected into sterile plastic tubes, and the tubes were capped and immediately stored at $-20{ }^{\circ} \mathrm{C}$ until analysis.

\section{Determination of SCD14 concentration}

The concentrations of sCD14 were determined in salivary supernatants, obtained by centrifuging the thawed saliva samples at $1800 \mathrm{~g}$ for $10 \mathrm{~min}$. All supernatants were diluted 10 times with assay dilution buffer before analysis. The 1:10 dilution gave the best signal-to noise ratio in the pre-validation study (results not shown). To eliminate any matrix effects, the standards were prepared by mixing pooled saliva ( $9 \mathrm{~mL} ; \mathrm{n}=5)$ of the caries-free subjects and the immunoassay buffer $(1 \mathrm{~mL})$. Quality controls were prepared in a similar manner by diluting the reference sample in $90 \%$ saliva. The concentrations of sCD14 were determined with the enzyme-linked immunosorbent assay (ELISA) using the commercial Enzo Life Science kit (Farmingdale, NY, USA; catalogue No. ALX-850-302KI01) according to the manufacturer's instructions. Briefly, the 1:10 saliva dilutions, matrix-matched standards, and the reference sample were captured on the solid phase by the POD-labelled monoclonal antibody specific to human sCD14. Five standards $\left(3.12-50 \mathrm{ng} \mathrm{mL}^{-1}\right)$ were used to generate the standard curve. When the antibody reacted with the substrate tetramethyl benzidine (TMB), we added a stop reagent to stop the reaction. The optical absorbance of each well was read at $450 \mathrm{~nm}$ using a Personal Lab plate reader (IASON, Graz Austria). Salivary sCD14 concentrations were calculated using linear regression analysis, multiplied by the dilution factor (10), and 
expressed in $\mathrm{ng} \mathrm{mL}^{-1}$. All samples were analysed in duplicate within three months of collection.

\section{Validation of the salivary sCD14 assay}

The assay was validated for both the resting and stimulated saliva. Validation included the determination of the detection limit (LOD), intra- and inter-assay coefficient of variation $(\mathrm{CV})$, and recovery in pooled saliva of five healthy subjects. The LOD was calculated as B+3SD, where $\mathrm{B}$ is the mean of 10 blank measurements, and SD is the standard deviation of these measurements. To determine intra-assay variation, we analysed one pooled saliva sample 10 times in a single run and calculated the mean, standard deviation, and coefficient of variation. Inter-assay variation was calculated based on these 10 measurements of the pooled sample over five days. Recovery was calculated by standard addition of pool saliva spiked with commercial sCD14.

The intra-assay variations for the resting and stimulated salivary sCD14 were 5.9 and $8.3 \%$, respectively. The interassay CVs were 11.6 and $8.9 \%$, respectively. Mean LOD was $4.9 \mathrm{ng} \mathrm{mL}^{-1}$ and mean recovery $86.5 \%$.

\section{Statistical analysis}

The clinical data were tested for normality of distribution with the Shapiro-Wilk W test. Non-normally distributed variables were compared with the Mann-Whitney $U$ test, and the $\mathrm{sCD} 14$ concentration and secretion rate data obtained from the two collection methods were compared with the Wilcoxon matched-pairs signed-rank test. The differences between the variables were tested with the chisquare and Fisher's exact tests.

The associations between the resting and stimulated salivary sCD14 and between sCD14 concentration and salivary flow rates were tested with the Spearman's rank correlation coefficient. We considered statistical significance for all tests at $\mathrm{P}<0.05$. All of the statistical analyses were performed using Dell Statistica, version 13 (Dell Inc., Tulsa, TX, USA).

\section{RESULTS}

Table 1 summarises and compares the demographic data, clinical symptoms, and some lifestyle characteristics between the participants with active caries and caries-free controls. There were no significant differences in the sex ratios, smoking, use of medicines, clinical symptoms of caries, or the DMFT index.

\section{Salivary sCD14 concentrations}

The caries-active group had significantly higher SCD14 concentrations both in the resting $(\mathrm{P}=0.004)$ and stimulated saliva ( $\mathrm{P}=0.001)$ (Figure 1). Furthermore, sCD14 levels differed significantly between the resting and stimulated saliva samples in the caries-free controls but not in cariesactive group ( $\mathrm{P}=0.990)$.

Resting saliva SCD14 significantly correlated with the stimulated saliva values $(\mathrm{r}=0.631, \mathrm{P}<0.05)$.

\section{Salivary flow rates}

The caries-active group showed significantly lower resting salivary flow than controls $(0.61 \pm 0.42 \mathrm{vs}$. $\left.0.98 \pm 0.52 \mathrm{~mL} \mathrm{~min}^{-1} ; \mathrm{P}<0.01\right)$. Low salivation $\left(<0.2 \mathrm{~mL} \mathrm{~min}^{-1}\right)$ was found in $26 \%$ of caries-active and $8 \%$ of caries-free participants, and hyposalivation $\left(<0.1 \mathrm{~mL} \mathrm{~min}^{-1}\right)$ was established only in the dental caries subjects (13\%) $(\mathrm{P}<0.05)$.

Stimulated salivary flow rates, however, did not differ significantly between the groups $\left(1.33 \pm 0.66 \mathrm{~mL} \mathrm{~min}^{-1}\right.$ in the caries-active $v s .1 .54 \pm 0.63 \mathrm{~mL} \mathrm{~min}^{-1}$ in the caries-free group; $\mathrm{P}=0.253$ ). Twenty percent in the caries-active and $8 \%$ in the control group had low salivary flow rate $\left(<1.0 \mathrm{~mL} \mathrm{~min}^{-1}\right)$. As with the resting saliva, hyposalivation

Table 1 Demographic and clinical data in the caries-free and dental caries groups

\begin{tabular}{|c|c|c|c|}
\hline Variable & $\begin{array}{c}\text { Caries-free } \\
(n=25)\end{array}$ & $\begin{array}{l}\text { Dental caries } \\
\quad(n=30)\end{array}$ & P values \\
\hline Male (n) & $11(37)$ & $9(36)$ & 0.184 \\
\hline Age (years, range) & $31(22-40)$ & $35(20-40)$ & 0.540 \\
\hline Non-smokers & $17(68)$ & $17(57)$ & 0.144 \\
\hline Smokers & $8(32)$ & $13(43)$ & 0.144 \\
\hline \multicolumn{4}{|l|}{ Clinical symptoms } \\
\hline Gingival bleeding on probing & $14(56)$ & $19(63)$ & 0.388 \\
\hline Dryness of mouth & $8(32)$ & $9(30)$ & 0.879 \\
\hline Burning mouth syndrome & $1(6)$ & $4(13)$ & 0.388 \\
\hline Use of medicines & $12(48)$ & $11(37)$ & 0.152 \\
\hline DMFT index & $13.8(0.1-21)$ & $16.5(2.0-26)$ & 0.080 \\
\hline Cavities & 0 & $6.8(1-19)$ & $<0.05^{\mathrm{a}}$ \\
\hline
\end{tabular}

${ }^{a}$ significant difference between the groups; DMFT - mean number of decayed, missing, and filled teeth 


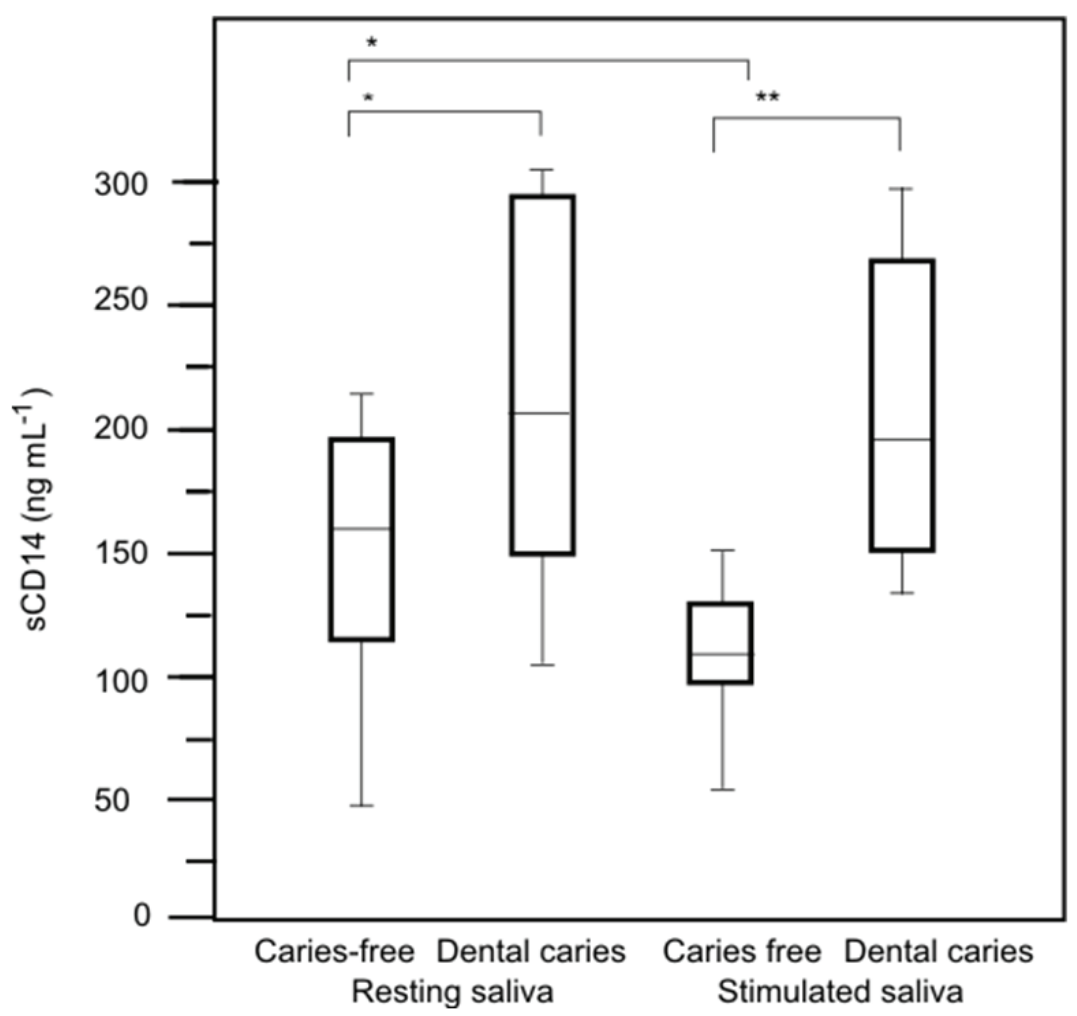

Figure 1 Resting and stimulated salivary sCD14 concentrations in caries-active and caries-free participants. The boxwhisker plot shows group medians, interquartile ranges (25-75\%), and the minimum and maximum values. $* P=0.004$; $* * P=0.001$

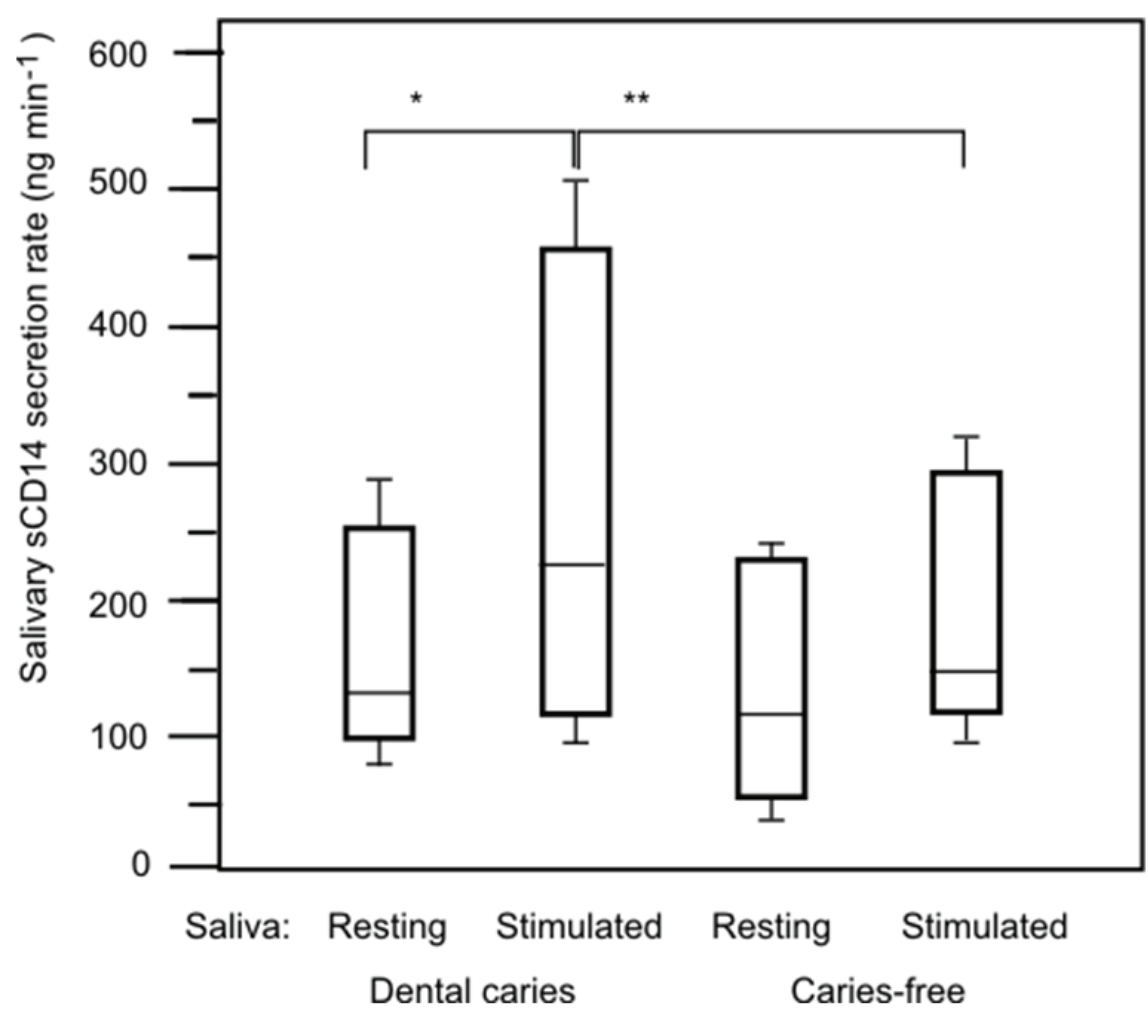

Figure 2 Resting and stimulated salivary sCD14 secretion rates in the caries-active and caries-free participants. The box-whisker plot shows group medians, interquartile ranges (25-75\%), and the minimum and maximum values. $* P=0.006 ; * * P=0.008$ 
was observed only in the caries-active group (10\%) $(\mathrm{P}<0.05)$.

\section{Correlation between sCD14 and salivary flow rate}

We also observed a weak negative correlation between sCD14 levels and salivary flow rates in caries-active subjects, irrespective of the collection method $(\mathrm{r}=-0.0896$ to $-0.1364 ; \mathrm{P}>0.05)$.

\section{Salivary sCD14 secretion rates}

The two groups did not differ in the median resting salivary $\mathrm{sCD} 14$ secretion rates $(\mathrm{P}=0.168)$, but the cariesactive group had significantly higher $\mathrm{SCD} 14$ secretion in the stimulated samples $(\mathrm{P}<0.01)$ (Figure 2). It also had significantly higher $\mathrm{SCD} 14$ secretion rates in the stimulated than the resting saliva $(\mathrm{P}<0.01)$.

\section{DISCUSSION}

Our findings have confirmed the hypothesis that sCD14 would be higher in caries-active than caries-free participants, and may suggest that the presence of dental caries is an important factor associated with salivary sCD14 levels. To the best of our knowledge, these are the first findings in adults, as earlier studies were focused on children $(12,23)$. Except in saliva, elevated sCD14 levels were reported in the serum of patients with chronic periodontitis $(28,29)$.

This brings us to another novelty of our research. Salivary immunoassays are often performed with the commercial kits designed for serum analysis. To the best of our knowledge, we have been the first to validate the ELISA for salivary sCD14 following the general recommendations by Jaedicke et al. (30) for validating ELISAs for the use with human saliva samples. Compared to serum analysis, our salivary sCD14 concentrations were approximately 20 times lower. However, the commercial ELISA was highly sensitive, and with slight modifications it was able to detect sCD14 in saliva. Similarly, Browne et al. (31) managed to repurpose some commercial immunoassays for the detection of several cytokines and chemokines in serum for their accurate quantification in saliva.

Our study has also confirmed the association between chronically low salivary flow rate and dental caries (32, $33)$. The prevalence of low salivary flow was 20-26\% (depending on the collection method) in the caries-active group and $8 \%$ in the controls. In other words, the risk of caries was about three times higher irrespective of the saliva collection method. Furthermore, hyposalivation was observed only in the caries-active group (10-13\% prevalence, depending on the saliva collection method). The prevalence of hyposalivation in the general population adults is high (10.9-17.8 \% in the resting and $0-5.5 \%$ in stimulated saliva) (34), which may give the reader an idea of the possible risk of caries in the general population.
We observed two interesting findings related to the salivary sCD14 secretion rates. They did not differ between the resting and stimulated saliva in controls $(\mathrm{P}=0.168)$ but soared significantly with stimulation in the caries-active group $(\mathrm{P}<0.01)$ (Figure 2). Does stimulation, therefore, set in motion mechanisms that mobilise pooled sCD14 and therefore reflect more truthfully the existing inflammation? This question remains to be answered in future studies. Another issue that needs addressing is the lack of a standardised procedure for routine saliva analysis in a clinical laboratory $(32,35)$.

In conclusion, our findings highlight the diagnostic potential of saliva. We have demonstrated that matrixmatched immunoassay for SCD14 quantification produced an acceptable analytical performance. Salivary sCD14 concentrations were significantly higher in the caries-active group than controls in both resting and stimulated saliva. Dental carries seems to affect both the salivary flow rate and salivary secretion rate. Future research should confirm the role of sCD14 in dental caries development and focus on its clinical application as a predictor of future caries events.

\section{Conflict of interest}

None to declare.

\section{Acknowledgments}

The authors are grateful to all the participants in this study.

\section{REFERENCES}

1. Selwitz RH, Ismail AI, Pitts NB. Dental caries. Lancet 2007;369:51-9. doi: 10.1016/S0140-6736(07)60031-2

2. Takahashi N, Nyvad B. Ecological hypothesis of dentin and root caries. Caries Res 2016;50:422-31. doi: $10.1159 / 000447309$

3. Trent MS, Stead CM, Tran AX, Hankins JV. Diversity of endotoxin and its impact on pathogenesis. J Endotoxin Res 2006;12:205-23. doi: 10.1179/096805106X118825

4. Hahn C-L, Liewehr FR. Relationship between caries bacteria, host responses, and clinical signs and symptoms of pulpitis. J Endodont 2007;33:213-9. doi:/10.1016/j.joen.2006.11.008

5. Uehara A, Sugawara S, Tamai R, Takada H. Contrasting responses of human gingival and colonic epithelial cells to lipopolysaccharides, lipoteichoic acids and peptidoglycans in the presence of soluble CD14. Med Microbiol Immunol 2001;189:185-92. Doi: 10.1007/s004300100063

6. Wang PL, Ohura K. Porphyromonas gingivalis lipopolysaccharide signaling in gingival fibroblasts-CD14 and toll-like receptors. Crit Rev Oral Biol Med 2002;12:13242. doi: $10.1177 / 154411130201300204$

7. Duncan L, Yoshioka M, Chandad F, Grenier D. Loss of lipopolysaccharide receptor CD14 from the surface of human macrophage-like cells mediated by Porphyromonas gingivalis outer membrane vesicle. Microb Pathog 2004;36:319-25. doi: 10.1016/j.micpath.2004.02.004 
8. Jin L. The in vivo expression of membrane-bound CD14 in periondontal health and disease. J Periodontol 2004;75:57885. doi: $10.1902 /$ jop.2004.75.4.578

9. Prester Lj, Varnai VM, Macan J. Soluble CD14 and total IgE in the serum of atopic and non-atopic adolescents in relation to environmental factors: a pilot study. Arh Hig Rada Toksikol 2015;66:41-9. doi: 10.1515/aiht-2015-66-2555

10. Isaza-Guzmán DM, Aristizábal-Cardona D, Martinez-Pabón MC, Velásquez-Echeverri H, Tobón-Arroyave SI. Estimation of SCD14 levels in saliva obtained from patients with various periodontal conditions. Oral Dis 2008;14:450-6. doi: 10.1111/j.1601-0825.2007.01400.x

11. Feghali A, Tanabe S, Grenier D. Soluble CD14 induces cytokine release by human oral epithelial cells. J Periodontal Res 2011;46:147-52. doi: 10.1111/j.1600-0765.2010.01311.x

12. Zhao A, Blackburn C, Chin J, Srinivasan M. Soluble toll like receptor 2 (TLR-2) is increased in saliva of children with dental caries. BMC Oral Health 2014;14:108. doi: 10.1186/1472-6831-14-108

13. Silva TA, Garlet GP, Fukada SY, Silva JS, Cunha FQ. Chemokines in oral inflammatory diseases: apical periodontitis and periodontal disease. J Dent Res 2007;86:30619. doi: $10.1177 / 154405910708600403$

14. Gornowicz A, Bielawska A, Bielawski K, Grabowska SZ, Wójcicka A, Zalewska M, Maciorkowska E. Pro-inflammatory cytokines in saliva of adolescents with dental caries disease. Ann Agric Environ Medicine 2012;19:711-6. PMID: 23311795

15. Stookey GK. The effect of saliva on dental caries. JAm Dent Assoc 2008;139(Suppl 2):S11-7. Doi: 10.14219/jada. archive. 2008.0347

16. Wang XP, Zhong B, Chen ZK, Stewart ME, Zhang C, Zhang K, Ni J, Dodds MWJ, Hanley AB, Miller LE. History of frequent gum chewing is associated with higher unstimulated salivary flow rate and lower caries severity in healthy Chinese adults. Caries Res 2012;46:513-8. doi: 10.1159/000339660

17. de Guillory CD, Schoolfield JD, Johnson D, Yeh C-K, Chen S, Cappelli DP, Bober-Moken IG, Dang H. Co-relationships between glandular salivary flow rates and dental caries. Gerodontology 2014;31:210-9. doi: 10.1111/ger.12028

18. Scully C. Drug effects on salivary glands: dry mouth. Oral Dis 2003,9:165-76. doi: 10.1034/j.1601-0825.2003.03967.x

19. Flink H, Tegelberg $\AA$, Lagerlöf F. Influence of the time of measurement of unstimulated human whole saliva on the diagnosis of hyposalivation. Arch Oral Biol 2005;50:553-9. doi: 10.1016/j.archoralbio.2004.10.015

20. Macdonald M, Azieman N, Ghani A, Wan Y, Cooper-White J, Dimeski G, Punyadeera C. Profiling of immunoglobulins in resting and mechanically stimulated saliva. Bioanalysis 2014;6:697-704. doi: 10.4155/bio.14.2

21. Navazesh M, Kumar SKS. Measuring salivary flow: Challenges and opportunities. Jam Dent Assoc 2008;139(Suppl 2):35S-40S. doi: 10.14219/jada.archive.2008.0353

22. Topkas E, Keith P, Dimeski G, Cooper-White J, Punyadeera C. Evaluation of saliva collection devices for the analysis of proteins. Clin Chim Acta 2012;413:1066-70. doi: 10.1016/j. cca.2012.02.020

23. Biria M, Sattari M, Vahid Golpayegani M, Kooshki F. Association of salivary sCD14 concentration levels with early childhood caries. Iran J Immunol 2010;7:193-7. doi: IJIv7i3A7

24. Faul F, Erdfelder E, Lang A-G, Buchner A. G*Power 3: A flexible statistical power analysis program for the social, behavioral, and biomedical sciences. Behav Res Methods 2007;39:175-91. doi: 10.3758/BF03193146

25. World Health Organization (WHO). Oral Health Survey: Basic Methods. $5^{\text {th }}$ ed, Geneva: WHO; 2013.

26. Kaur A. Kwatra KS, Kamboj P. Evaluation of non-microbial salivary caries activity parameters and salivary biochemical indicators in predicting dental caries. J Indian Soc Pedod Prev Dent 2012;30:212-7. doi: 10.4103/0970-4388.105013

27. Dukić W, Trivanović Dobrijević T, Katunarić M, Lešić S. Caries prevalence in chronic alcoholics and the relationship to salivary flow rate and pH. Cent Eur J Public Health 2013, 21:43-47. PMID: 23741900

28. Hayashi J, Masaka T, Ishikawa I. Increased levels of soluble CD14 in sera of periodontitis patients. Infect Immun 1999;67:417-20. PMCID: PMC96326

29. Nicu EA, Laine ML, Morré SA, Van der Velden U, Loos BG. Soluble CD14 in periodontitis. Innate Immun 2009;15:1218. doi: $10.1177 / 1753425908101577$

30. Jaedicke KM, Taylor JJ, Preshaw PM. Validation and quality control of ELISAs for the use with human saliva samples. J Immunol Methods 2012;377:62-5. doi: 10.1016/j. jim.2012.01.010

31. Browne RW, Kantarci A, LaMonte MJ, Andrews A, Hovey KM, Falkner KL, Cekici A, Stephens D, Genco RJ, Scannapieco FA, Van Dyke E, Wactawski-Wende J. Performance of multiplex cytokine assays in serum and saliva among community-dwelling postmenopausal women. PLoS One 2013;8:e59498. doi: 10.1371/journal.pone.0059498

32. Dodds MWJ, Johnson DA, Yeh C-K. Health benefits of saliva: a review. J Dent 2005;33:223-33. doi: 10.1016/j. jdent.2004.10.009

33. Animireddy D, Bekkem VTR, Vallala P, Kotha S, Ankireddy $\mathrm{S}$, Mohammad N. Evaluation of $\mathrm{pH}$, buffer capacity, viscosity and flow rate levels of saliva in caries-free, minimal caries and nursing caries children: An in vitro study. Contemp Clin Dent 2014;5:324-8. doi: 10.4103/0976-237X.137931

34. Flink H, Bergdahl M, Tegelberg A, Rosenblad A, Lagerlöf F. Prevalence of hyposalivation in relation to general health, body mass index and remaining teeth in different age groups of adults. Community Dent Oral Epidemiol 2008;36:523-31. doi: 10.1111/j.1600-0528.2008.00432.x

35. Nunes LAS, Mussavira S, Bindhu OS. Clinical and diagnostic utility of saliva as a non-invasive diagnostic fluid: a systemic review. Biochem Med 2015;25:177-92. doi: 10.11613/ BM.2015.018 


\section{sCD14 u slini kao biljeg aktivnosti zubnoga karijesa u odraslih}

CD14 je koreceptor uključen u prepoznavanje Gram-negativnih i Gram-pozitivnih bakterija. Cilj ovoga istraživanja bio je ispitati povezanost između aktivnosti zubnoga karijesa i razine topivoga CD14 (sCD14) u slini odraslih osoba. Također smo ispitali utjecaj metode skupljanja sline na koncentraciju sCD14. U istraživanju je sudjelovalo 55 ispitanika u dobi od 20 do 40 godina: 30 ispitanika sa zubnim karijesom i 25 bez karijesa (kontrola). Ukupno smo skupili 110 uzoraka: 55 nestimulirane i 55 mehanički stimulirane sline. Medijan koncentracije sCD14 u slini, izmjerene enzim-imunokemijskom metodom (ELISA), bio je viši u ispitanika s karijesom, i to u nestimuliranoj $\left(203,3\right.$ prema $\left.167,9 \mathrm{ng} \mathrm{mL}^{-1}, \mathrm{P}<0,01\right) \mathrm{kao}$ i u stimuliranoj slini (201 prema $105,7 \mathrm{ng} \mathrm{mL}^{-1}, \mathrm{P}<0,01$ ) u usporedbi s kontrolnom skupinom. Ustanovljena je značajno niža razina lučenja sline u ispitanika s karijesom negoli u kontrolnoj skupini $\left(0,61 \pm 0,42\right.$ prema $0,98 \pm 0,52 \mathrm{~mL} \mathrm{~min}^{-1}$, $\mathrm{P}<0,01)$. Hiposalivacija je ustanovljena samo u skupini sa zubnim karijesom (10-13 \% u stimuliranoj i nestimuliranoj slini). Ustanovili smo da koncentracija sCD14 u slini, kao i brzina protoka sline, ovisi o metodi skupljanja sline i aktivnosti zubnoga karijesa. Klinička primjena određivanja koncentracije sCD14 kao potencijalnoga biljega i prediktora upale kod zubnoga karijesa trebala bi se dalje ispitati.

KLJUČNE RIJEČI: ELISA; hiposalivacija; nestimulirana slina, razina lučenja sline; stimulirana slina 